\title{
SOME GROSS ANATOMICAL STUDIES ON THE PULMONARY VEINS IN THE DONKEY (EQUUS ASINUS).
}

\author{
Farag, F.M.M
}

Lecturer of Anatomy, Anat. Dept. Fac. Vet. Med. Cairo Univ.

\section{ABSTRACT}

The pulmonary veins were studied on fifteen lungs of donkeys of different ages. The pulmonary veins were injected with colored mass of kemo-apoxy No. 151/20A, as well as 30\% suspension of red lead oxide in kemo-apoxy No. 150 for cast formation and radiographic investigation respectively. The present study had revealed that, The pulmonary veins were released from three sinuses of the left atrium; right, left and caudal. The right sinus gave off; the v. pulmonalis lobi cranialis dextri as well as the first and second ventral segmental rami of the right caudal lobe. The left sinus detached the v. pulmonalis lobi cranialis sinistri, while the caudal sinus gave rise to both $V v$. pulmonales lobi caudales, v. pulmonalis lobi accessorius as well as the first and second ventral segmental branches of the left caudal lobi. The lobar veins were valueless, while the origin of the majority of the segmental veins was guarded by a cresenteric flap. Nine to ten pulmonary veins collected the blood from both lungs.

The obtained results had also revealed that the left lung comprised 12-13 venous segments, while the right one constituted 15-16 ones. Bronchovascular segmentation can be observed only in the accessory lobe and the caudal segment of both caudal lobes, while the remaining of the lung was bronchoarterially segmented and the venous segmental rami were intersegmentally placed. 


\section{INTRODUCTION}

The clinical importance of the pulmonary vasculature had received the attention of many authors. However both the origin and main branches of these vessels were studied by Guzsal (1955) in the domestic animals, Schorono (1955) in the cattle, Barone (1953) and Ehrsam (1957) in the horse, Swielim (1981) in the goat, Hagrass (1982) in the buffalo as well as by Osman/Abu-Zaid (1986) in the donkey.

The present study is an attempt to give additional informations about the pulmonary veins of the donkey which still remains of fundamental practical and clinical importance.

\section{MATERIAL AND METHODS}

The present study was carried out on fifteen lungs with intact hearts collected from donkeys of different ages. The animals were embalmed using $10 \%$ formalin solution, as a fixative. The specimens were injected through a canula introduced into the left ventricle, after legation of the origin of the aorta.

Nine specimens were used for cast formation and manual dissection while the rest of the specimens were used for radiographic study.

\section{Injection masses used:}

1. Cast formation mass: comprises red kem-apoxy No. 151/20 A mixture of solutions $\mathrm{A} / \mathrm{B}$ in a radio of $3: 1$ respectively.

2. Radio - opaque mass: composed of $30 \%$ suspension of red lead oxide colorless in kemo-apoxy No. 150. 2A:1B and then radio graphed at $55 \mathrm{k} \mathrm{v} 30-70 \mathrm{MA}, 0.5$ second and FFd $70 \mathrm{~cm}$.

Caliber used for measuring the diameter of the main vessels.

The nomenclature used was those adopted by the electronic version of the Nomina Anatomica Veterinaria (2005) as well as those used by other investigators dealing with the study of the pulmonary vessels. 


\section{RESULTS}

The veins of both lungs are given from the three sinuses of the left atrium. The three sinuses may be designated according to their location in the atrium as; right, left and caudal sinuses. However, in six of the examined specimens, the left atrial sinuses were represented only by the right and caudal sinuses.

\section{Sinus dexter:}

The right sinus (fig. 1,2,3 / 3 ) is connected with the dextrocaudal aspect of the left atrium. It measures about $3.5 \mathrm{~cm}$. in length and $2.0 \mathrm{~cm}$. in diameter. It gives off; the right cranial pulmonary vein as well as the first and second ventral segmental branches of the caudal lobe of the right lung.

v. pulmonalis lobi cranialis dextri (fig. 1,2,3/6) springs from the craniodorsal aspect of the right sinus of the left atrium and proceeds in a craniodorsal direction along the dorsal aspect of the cranial bronchus for about $3.0 \mathrm{~cm}$. and divides into two segmental branches; caudal and cranial. However,in 3 of the examined specimens, the right cranial lobar pulmonary vein terminates into three segmental branches; cranial, middle and caudal .

R.segmentalis caudalis (fig. 1,2,3 /7) swerves caudodorsally and follow the caudal aspect of the corresponding bronchus to ramify in the caudal portion of the right cranial lobe.

R. segmentalis cranialis (fig. 1,2,3 /8) represents the direct containuation of the right cranial pulmonary vein along the ventromedial aspect of the corresponding bronchus. It releases 4-5 dorsal and 3-4 ventral collateral bronches which follow the same arborization pattern of the corresponding segmental and subsegmental branches of the right cranial bronchus. 


\section{Sinus sinister:}

The left sinus (fig. 1,2,3/4) is the smallest of the three sinuses of the left atrium. It measures about $2.0 \mathrm{~cm}$. in length and $1.0 \mathrm{~cm}$. in diameter. It is connected with the left dorsal wall of the left atrium, just dorsolateral to the caudal sinus. It gives off the v. pulmonalis lobi cranialis sinistri. However, in six of the examined specimens the left atrial sinus was absent and the later vein extended in its same size to terminate into the caudal sinus.

V. pulmonalis lobi cranialis sinistri (fig. 3/9) represents the direct continuation of the left sinus of the left atrium. It passes laterally,about 1 $\mathrm{cm}$ to reach the lateral aspect of the left cranial bronchus, where it divides into the caudal (fig. 1,2,3/10) and the cranial (fig. 1,2,3/11) segmental branches of the left cranial lobe. Both segmental bronches, follow the same arborization pattern of the corresponding branches of the right lobe. However, in three of the dissected specimens the later two segmental rami originated separately from the left sinus.

\section{Sinus caudalis:}

The caudal sinus (fig. 1,2,3/5) is the largest of the three sinuses of the left atrium. It is formed by the caudodorsal wall of the left atrium and lies ventral to the tracheal bifurcation. It measures about $4.0 \mathrm{~cm}$. in length and $3.0 \mathrm{~cm}$. in diameter. It gives off; the v. pulmonalis lobi caudalis dextri, v. pulmonalis lobi caudalis sinstri, v. pulmonalis lobi accessorius as well as the first and second ventral segmental bronches of the left caudal lobe.

V. pulmonalis lobi caudalis dextri (fig. 1,2,3/ 12) is the widest of the pulmonary veins. It measures about $1.8 \mathrm{~cm}$. in diameter,at its origin from the caudal sinus. It proceeds caudolaterally, crosses the dorsal aspect of the accessory bronchus and continues caudally, along the 
dorsomedial aspect of the right caudal bronchus and terminates into two rami dorsal (fig. 2 / 13) and vental (fig. 2 / 14). Throughout its course, the right caudal pulmonary vein supplies the right caudal lobe through the third, fourth and fifth ventral segmental Rami as well as through variable number of dorsal segmental branches.

Rr. segmentales ventrales (fig. 1,2,3 / 15) are represented by five veins supplying the ventral segments of the caudal lobe of the right lung. It is observed that the Rr. Segmentales ventrales I and II arise directly from the right sinus of the left atrium, while the III, IV and V ones originate from the right caudal lobar pulmonary vein. Moreover, these segmental branches, decrease gradually in size and length, from the first to the fifth. However, each of these veins extends ventrolaterally towards the acute border of the lung, midway between two successive ventral segmental bronchi and arteries, in an alternative manner to terminate into a cranial (fig. 1,2/ 16) and a caudal (fig. 1,2 / 17) branch. Along its courses, each of the Rr. Segmentales ventrales receives 5-6 cranial and caudal collateral Rami, from the adjacent cranial and caudal arterial segments.

Rr. segmentales dorsales (fig. 1,2/ 18) are represented by 5-6 branches, of smaller size than the corresponding ventral ones, with which they usually originate in an alternative pattern. Each of these rami follow a short caudodorsal course towards the obtuse border of the lung where it divides into 2-3 branches which arborizes in the the dorsal venous segments of the caudal lobe.

V. pulmonalis lobi caudalis sinistri (fig. 1,2,3 / 19) simulates the corresponding right one in both its size and branching pattern. Also it plays the same role in draining the left caudal lobe. Moreover it may be $\overline{\text { Kafrelsheikh Vet. Med. J. Vol. } 6 \text { No. } 1 \text { (2008) }}$ 
relevant to point out that, the $\mathrm{Rr}$ segmentales ventralis(fig. 1,2,3/22) of the left caudal pulmonary lobe were only four in number. Moreover, the first and second rami of those branches originated directly from the caudal sinus of the left atrium, while the third and fourth ones arose from the $\mathrm{v}$. pulmonalis lobi caudalis sinistri. It is to add that in 3 of the examined specimens, only the first ventral segmental branch was observed to arise from the caudal sinus, while the second, third and fourth rami emnated from the v. pulmonalis lobi caudalis sinistri. However apart from the different origin of these Rr. Segmentales ventrales. each follow the same arborization pattern of the corresponding rami of the right caudal lobe.

V. pulmonalis lobi accessorii (fig. 3/ 26) erupts from the caudal sinus of the left atrium, between the right and left caudal lobar pulmonary veins. It proceeds caudally, for about $2.0 \mathrm{~cm}$. along the medial aspect of the accessory bronchus then it divides into two segmental branches; medial (fig 1/27) and lateral (fig. 1/28). Each of these two rami divides into 3-4 smaller branches which follow entirely the subsegmental bronchii. It is to be added that variation as regard the origin of the $\mathrm{V}$. pulmonalis lobi accessorii and its terminal segmental branches were observed among the examined specimens. In three of the examined specimens, the medial and lateral segmental rami erupted separately from the caudal sinus while in three other specimens, the v. pulmonalis lobi accessorii emanated from the initial portion of the v. pulmonalis lobi caudalis dexter, near its origin from the caudal sinus. Moreover but, in another three specimens, the medial segmental branch arises from the caudal sinus of the left atrium, while the lateral one erupted from the right caudal lobar pulmonary vein. 
The main lobar vein does not contain any valves. On the other hand, the origin of each segmental vein is guarded by semilunar cresenteric flap (fig. 4 / 29).

The summation of the pulmonary veins of both lungs is 9-10 in number, 5-6 from the right lung and 4 from the left one.

\section{VENOUS SEGMENTATOIN OF THE LUNGS}

The present investigation has revealed that, the lobar veins accompany their satellite lobar brochii and arteries. On the other hand the segmental tributaries of these veins does not follow the same branching pattern of the corresponding segmental arteries, except for the accessory lobe and the caudal segment of the caudal lobe. In the later two lobes, the arterial and venous segmental branches are similar, i.e bronchvascular.

The cranial lobes of both lungs are divided into two venous segments; cranial (1/10) and caudal(2/10). However, in three of the examined specimens, the right cranial lobe was divided into three venous segments; cranial, middle and caudal.

The accessory lobe is divided into two segments; medial (6/10) and lateral (7/10) drained by the medial and lateral tribularies of the V. pulmonalis lobi accessorii.

The caudal lobes of both lungs can be divided into dorsal (3/10) and ventral (4/10) raws of segment in addition to a caudal segment. The segments of these two raws are supplied by the corresponding dorsal and ventral segmental Rami of the v. pulmonalis lobi caudalis, while the caudal segment $(5 / 10)$ is drained by the terminal branches of the later vein.

The total number of the venous segments is therefore $12-13$ in the left lung and 15-16 in the right one. 
Fig. (1-4): distribution of pulmonary veins in the lung of the donkey.

1- Atrium sinistrum.

2- Auricula sinista.

3-Sinus dexter.

4- Sinus sinister

5- sinus caudalis.

6- V.pulmonalis lobi cranialis dextri.

7- R.segmentalis caudalis of 6 .

8- R.segmentalis cranialis of 6.

9- V.pulmonalis lobi cranialis sinistri.

10- R.segmentalis caudalis of 9 .

11- R.segmentalis cranialis of 9.

12- V.pulmonalis lobi caudalis dextri.

13- R.dorsalis of 12.

14- R.ventralis of 12.

15- Rr.segmentales ventrales of 12 .
16- R.cranialis of 15 .

17- R.caudalis of 15 .

18- Rr.segmentales dorsales of 12 .

19- V.pulmonalis lobi caudalis sinistri.

20- R.dorsalis of 19.

21- R.ventralis of 19.

22- Rr.segmentales ventrales of 19 .

23- R.cranialis of 22.

24- R.caudalis of 22.

25- Rr.segmentales dorsales of 19.

26- V.pulmonalis lobi accessorii.

27- R.segmentalis medialis of 26.

28- R.segmentalis lateralis of 26.

29- Vulvular flaps.
A. Lobus cranialis dexter.
B. Lobus caudalis dexter.
C. Lobus cranialis sinister.
D. Lobus caudalis sinister
E. Trachea.

Fig. (5): Venous segmentation of the lung of the donkey.
A. Dorsal view.
4. Ventral segments of the caudal lobe.
B. Ventral view.
5. Caudal segment of the caudal lobe.
1. Cranial segment of the cranial lobe.
6. Medial segment of the accessory lobe.
2. Caudal segment of the cranial lobe.
7. Lateral segment of the accessory lobe.
3. Dorsal segments of the caudal lobe. 


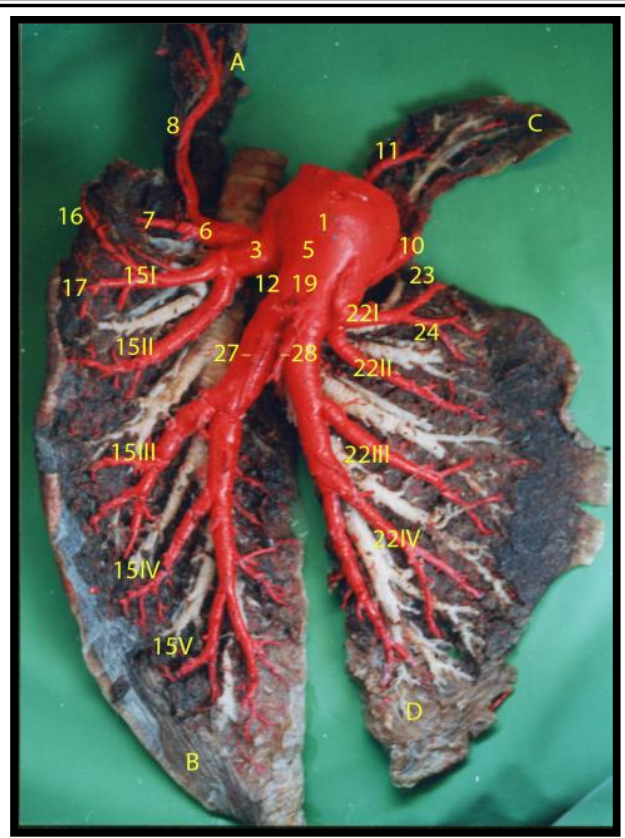

Fig. (1): Ventral view of kem apoxy cast of the pulmonary veins of the donkey, manually dissected.

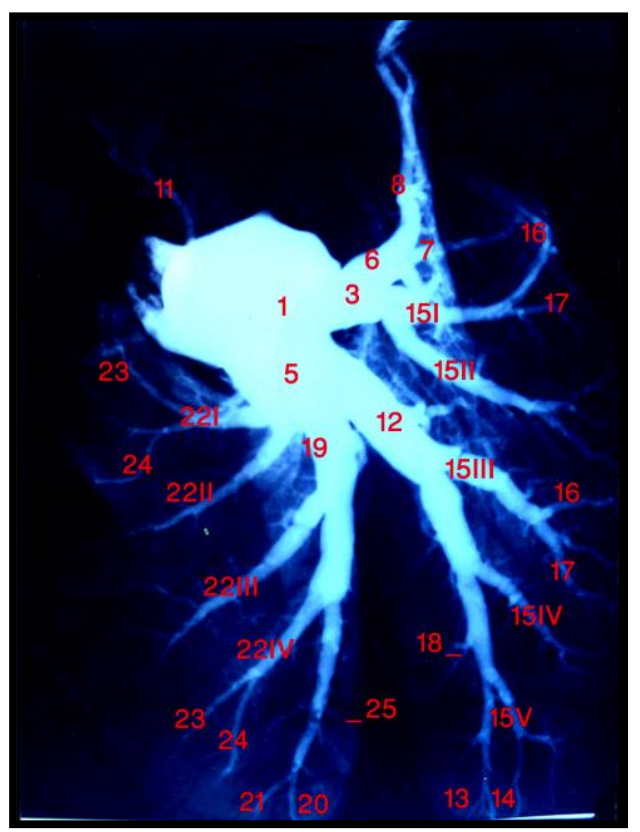

Fig. (2): Radiographic picture of the pulmonary veins of the donkey, radiographed at 55k v 30-70 MA, 0.5 second and ffd $70 \mathrm{~cm}$. 


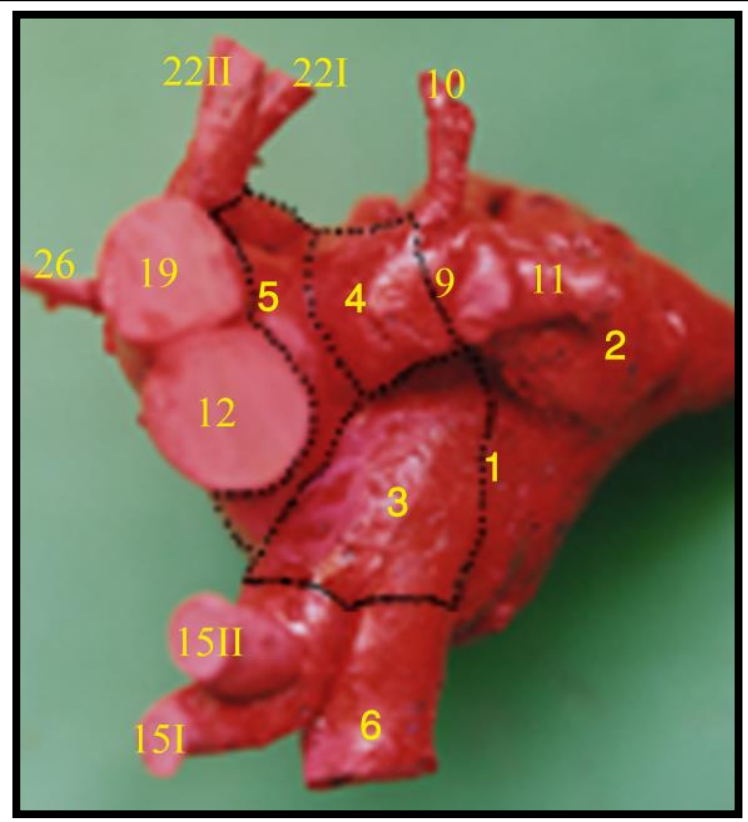

Fig. (3): Dorsal view of kem apoxy cast of the left atrium of the donkey. Dotted lines indicated the limits of the three sinuses of the atrium.

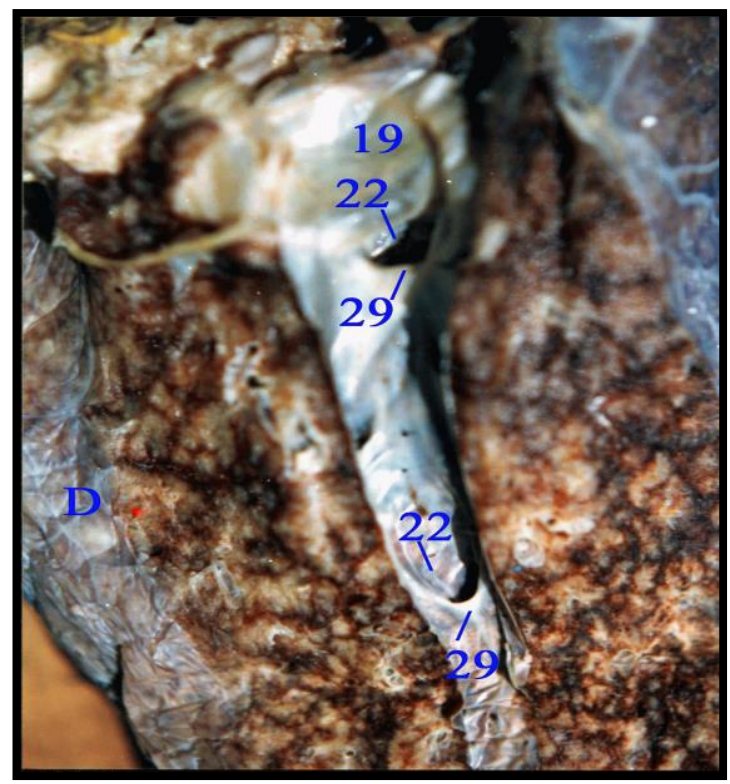

Fig. (4): A longitudinal incission through the v.pulmonalis lobi caudalis sinistri, showing the vulvular flaps guarding the origin of the segmental veins. 


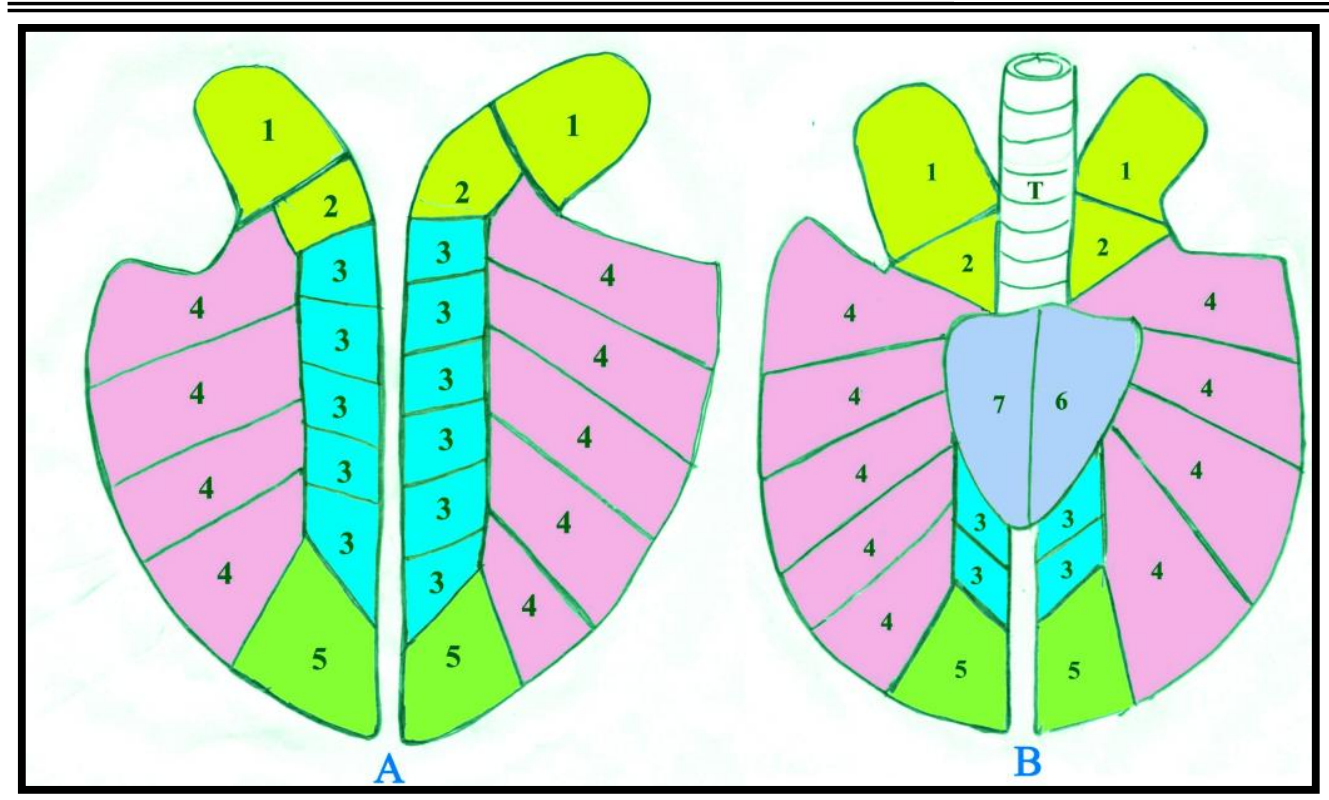

Fig. (5): Diagrammatic representation showing the venous segmentation of the lung of the donkey.
A. Dorsal view.
B. Ventral view.

\section{DISCUSSION}

The current investigation recorded that, the pulmonary veins of both lungs were given off from the sinuses of the left atrium. These sinuses can be demonstrated and were designated, according to their position as right, left and caudal sinuses. Similar finding were reported by Guzsal (1955), in the dog, big, ruminats and horse and Osman (1974) in the camel. In this connection, it may be relevant to point out that, Zsegyenov (1923) in equines designated theses sinuses as; left, right and middle sinuses, while Martin (1923) in the domestic animals, designated the sinuses as left cranial, left caudal and right ones. 
Moreover, these sinuses were named as left cranial, right cranial and caudal sinuses as mentioned by Barone (1958), Felder (1962) and Wilkens /Munster (1976) in the dog, Sweilim (1981) in the goat, Hagrass (1982) in the buffalo, Sweilim /Hagrass/ Ragab (1987) in the sheep as well as by Osman/Abo-Zaid (1986) in the donkey. However, in $50 \%$ of the examined specimens, the left sinus was absent and the pulmonary veins were given off from the right and caudal sinuses. Barone (1953) in the horse gave a similar findings and described the two sinuses of the left atrium as a larger left sinus and a smaller right one.

According to the present study, the right sinus of the left atrium gave off the right cranial pulmonary vein, as wall as the first and second ventral segmental rami of the right caudal lobe. On the other hand, Osman/Abu-Zaid (1986) in the same animal mentioned that the corresponding sinus detached the right cranial pulmonary vein and only the first ventral segmental vein of the right caudal lobe. It might be added that, the corresponding sinus in the goat (Swielim, 1981), buffalo (Hagrass, 1982) and sheep (Swielim et al., 1987) gave off the right cranial as well as the middle pulmonary veins, which drain the right cranial and middle lobes respectively and did not share in draining the caudal lobe.

In accordance with Osman/Abu-Zaid (1986) in the donkey, the right cranial pulmonary vein collects the blood from the cranial lobe of the right lung through two segmental rami; cranial and caudal. Similarly Swielim et al (1987) in the sheep recorded the division of the v. pulmonalis cranialis dexter into two rami; R. ascendens and R. descendens which drain the cranial and caudal sub division of the right cranial lobe. It is to add that, in three of the examined specimens in the present work, the right cranial pulmonary vein was trifurcated into three rami, cranial middle and caudal, draining the lobe. Nearly similar Kafrelsheikh Vet. Med. J. Vol. 6 No. 1 (2008) 
observations were recorded by Barone (1958), Felder (1962) and Nickel et al. (1976) in the dog who stated that, the right cranial pulmonary vein was represented by three independent veins, draining the cranial lobe of the right lung and opened directly into the right cranial sinus.

The current investigation revealed that, the left atrial sinus gave only the left cranial pulmonary vein which drain the cranial lobe of the left lung. On the other hand, Osman/Abu-Zaid (1986) in the donkey added that, the corresponding sinus also released the first and second ventral segmental branches of the left caudal lobe. An observation which cannot be observed in any of the examined specimens in the present study and the later two rami were given off directly from the caudal sinus of the left atrium.

In agreement with Osman/Abu-Zaid (1986) in the donkey, the left cranial pulmonary vein in present work was divided into two segmental branches; cranial and caudal. However, in three of the dissected specimens, the later branches originated separately from the left sinus. An observations which simulate Those given by Barone (1958), Felder (1962) in the dog as well as Swielim et al. (1987) in the sheep.

The present work revealed the origin of both right and left caudal lobar as well as the accessory pulmonary veins from the caudal sinus. Similar findings were recorded by Osman/ Abu-Zaid (1986) in the donkey. On the other hand, Hagrass (1981) in the buffalo, Swielim (1981) and Roos/Hegner/Volmerhus (1999) in the goat and Swielim et al. (1987) in the sheep reported that the accessory pulmonary vein was given off from the right caudal pulmonary vein. A result which could be demonstrated in three of the current examined specimens. It is to add that, the accessory pulmonary vein was divided into two segmental branches; medial and lateral. Similarly Swielim et al. (1987) in the sheep reported the division of the accessory lobar vein into dorsal and ventral 
rami. Moreover, it might be relevant to point out that in three of the examined specimens (25\%), the medial and lateral branches arose independently from the caudal sinus and in three other specimens, the medial ramus emanated from the caudal sinus, while the lateral one was given off from the right caudal pulmonary vein.

The result obtained by Osman (1974) in the camel, Swielim (1981) in the goat, Hagrass (1982) in the buffalo, Osman/Abu-Zaid (1986) in the donkey and Swielim et al. (1987) in the sheep, that all the lobar pulmonary veins as well as their segmental and subsegmental division were vulveless could be accepted for the main lobar veins only. On the contrary, the origin of each of the segmental vein was marked by constriction and was guarded by a sort of valve, in the form of cresentric flap.

According to the present work, the total number of the pulmonary veins of both lungs was 9-10. In this connection Backman (1937) recorded that, the main pulmonary veins of the domestic animals were four in the right lung and two in the left one. Moreover Barone (1953) recorded the presence of 11-13 vein in the horse, while Osman/AbuZaid (1986) reported only seven pulmonary veins in the donkey.

schorono (1955) in the cattle, Swielim (1981) in the goat, Hagrass (1982) in the buffalo, Swielim et al. (1987) in the sheep and Osman (1989) in the deer, recorded that the branches of the pulmonary veins followed the same arborization pattern of the segmental and subsegmental bronchii in all lobes of the lung and consequently the broncho-pulmonary segmentation was of the broncho vascular type . However,in view of the present results this observation can be applied favourably on the accessory lobe as well as on the caudal segment of the caudal lobe. On the other hand the cranial and most of the caudal lobes were bronchoarterially segmented where the branches of the pulmonary veins were intersegmentally placed. In this regard Osman/Abu-Zaid (1986) in the donkey, recorded that,both the cranial and the accessory $\overline{\text { Kafrelsheikh Vet. Med. J. Vol. } 6 \text { No. } 1 \text { (2008) }}$ 
lobes were of bronchovascular segmentation type, while the entire caudal lobes were bronchoarterial. Moreover Osman/ Arnautovic/ El-Khaligy (1985) in the rabbit mentioned that the middle lobe as well as both the caudal lobes are bronchoarterially segmented. On the contrary wilkens/ Munster (1976) in the pig, dog and cat reported that the segments of the caudal lobes were of bronchovascular type, while those of the other lobes were bronchoarterial. On the other hand the later type of segmentation was observed in all pulmonary lobes as mentioned by Barone (1953) and Ehrsam (1957) in the horse as well as by Wilkens/Munster (1976) in both horse and sheep.

\section{REFERENCS}

- Backmann, G. (1937): Die Lungenvenen der Wirbeltiere. Lunds Universitets Arsskr. N. F. Avd. 2; 33:1-112.

- Barone, R. (1953): Arbre bronchique et vaisseaus sanguins des poumons chez Les Equidés domestiques. Rec. Méd. Vet. 129: 545 563.

- Barone, R. (1958): Arbre bronchique et vaisseaux pulmonaires chez le chien. Compt. rend. Ass, Anat. 97:132 - 144.

- Ehrsam, H. (1957): Die Lappen Und Segmente der Pferdlunge und ihre Vaskularisation. Zurich, Univ, Vet. med. Fak., Diss..

- Felder, G. (1962): Beitrag zur Segmentanatomie der Hundelunge. Zurich, Univ., Vet. med. Fak., Diss.o

- Guzsal, E. (1955):The topography of blood vessels and of the bronchial tree of domestic animals.Acta. Anat. Vet. Vol. V., 333-365.

- Hagrass, M.S. (1982):Some anatomical studies on the lung of the buffalo in Egypt (Bos bubalis). Thesis Ph. D. in anatomy and embryology, Faculty of Veterinary Medicine Cairo University. 
- Martin,P. (1923): Lehrbuch der Anatomie der Haustiere. Band, 4:Anatomie des Schweines, des Hundes und der Katze. Verlag von Schickhardt und Ebner, Stuttgart.

- Nomina Anatomica Veterinaria (2005) : $5^{\text {th }}$ Ed. Prepared by the international committee on Veterinary Gross Anatomical Nomenclature. General Assembly of the word Association of veterinary anatomists, Knoxville, TN (U.S.A.) 2003. Hannover, Columbia, Gent, Sapporo. (Electronic version).

- Osman, F.A. (1974): Some anatomical studies on the bronchial tree and pulmonary vessels of the dromedary camel (Camelus dromedarius). Thesis M.V. Sc., Cairo Univ., Fac. Vet. Med.

- Osman, F.A. (1989): Anatomical studies on the bronchial tree and pulmonary blood vessels in the deer (dorcas gazel). Part I: bronchial tree and pulmonary trunk. Egypt. J. Anat., Vol. 12 (2, 91-103).

- Osman, F.A. and Abu-Zaid, M.S. (1986): Topographical anatomical studies on the pulmonary veins of the donkey (Equus asinus). Assiut Vet. Med. J., Vol. 17, No. 34, 18-25.

- Osman, F. A., Arnautovic, I. and El-Khaligi, G. M. (1985): Intrapulmonary distribution of bronchi and pulmonary blood vessels in rabbits. Alex. J. Vet. Sci.,1 No. 2,20-31.

- Roos, H., Hegner. K. and Vollmerhaus, B. (1999): Die vasa pulmonalis der Hausziege. Anat. Histol. Embryol. 28, 131-137.

- Schorono,E. (1955):Die lappen und segmente der Renderlung und deren Vaskularisation. Zurich Diss. Vet. Med

- Swielim,G.E.A.,(1981): Anatomical studies on the lung of the goat. Thesis Ph.D. in Anatomy and Embryology, Faculty of Veterinry Medicine, Cairo University.

- Swielim,G. E. A., Hagrass, S. M. and Ragab, S. A. (1987): Intrapulmonary distribution of the pulmonary vessels in sheep. Egypt. J. Anat., Vol.10 (1)p.p. 65-76.. 
- Wilkens, H. and Munster,W. (1976): Arterian und Venen: In Nickel, R., Schummer, A. and Seiferle,E. Lehrbuch der Anatomie der Haustier. Bd. III Verlag Paul Parey, Berlin, Hambourg. p.p. 41 - 74.

$$
\text { بعض الدر اسات التشريحية على الاورده الرئوية في الحمار. }
$$$$
\text { قسم التثريح - كلية الطب البيطري - جامعة القاهرة }
$$

أجرى البحث على خمسه عشر رئة من الحمير المختلفة الأعمار والجنس. وقد ثم حقن تسع منها بكتلة عمل القوالب المكونة من الكيمو اييوكسى الأحمر رقم 151/20A ، أما باقى العينات فقد تم حقنها بالكتلة الظليلة على الإثعاع المكونة من أكسيد الرصاص الأحمر المعلق في الكيمو ايبوكسى الثفاف رقم

55 KVP 30-70 MA, 0.5 second and FFD 70 cm. ثم تعرضت للإثشعاع بقوة وقد بينت الدراسة الآتي: أن الأوردة الرئوية في الحمار عددها 9-10 وتخرج من جيوب البهو الأيسر وهم ثلاثة جيوب , الجيب الأيمن والأيسر والخلفى ، ا الجيب الأيمن يعطي وريد الفص الأمامي وكذا وريدا الفلقه البطنيه الأولى والثانيه للفص الخلفي الأيمن والجيب الأيسر فيخرج منه وريد الفص الأمامي الأيسر ـ أما الجيب الخلفي فيخرج منه وريدا الفص الخلفي لكلا الرئتين وكذا وريد الفص الإضافي و وريدا الفلقه البطنيه الأولى والثانيه للفص الخلفي الأيسر. كما تم عمل تفلق لكلا من الرئتين وفقا للتقرعات الأوردة الرئوية وقد وجد أن الرئة اليسرى تتقم إلى 12-13 فلقة وريدية بينمت نتقسم الرئة اليمنى إلى 15-16 فلقة وريدية وقد بينت الدراسة أن 
الفلقات الثريانية والوريدية تتطابق فقط فى الفص الإضافي والفلقه الخلفيه للفصين الخلفيين ،أما في باقي الرئة فتتداخل الفلقات الثريانية والوريدية مع بعضها البعض.وقد استخدت المسميات المتداولة في الاصدار الالكترونى (2 005) 2.A.V. - (2) 